Meynell, G. G. \& Stocker, B. A. D. (1957). J. gen. Microbiol. 16, 38-58

\title{
Some Hypotheses on the Aetiology of Fatal Infections in Partially Resistant Hosts and their Application to Mice Challenged with Salmonella paratyphi-B or Salmonella typhimurium by Intraperitoneal Injection
}

\author{
By G. G. MEYNELL \\ Departments of Bacteriology, London School of Hygiene and Tropical Medicine \\ and Postgraduate Medical School of London,* Ducane Road, London, W. 12 \\ AND B. A. D. STOCKER \\ Guinness-Lister Unit, Lister Institute of Preventive Medicine, \\ London, S.W. 1
}

SUMMARY: Some hypotheses are considered which describe the aetiology of a fatal infection in a partially resistant host; i.e. a host which does not invariably die after inoculation with one bacterium. The hypothesis of independent action postulates that the mean probability per inoculated bacterium of multiplying to cause (or help to cause) a fatal infection is independent of the number of bacteria inoculated and, for a partially resistant host, is less than unity $(1>p>0)$. It predicts: $(1)$ that the slope, $b$, of the probit-mortality/log-dose curve will be $2 \cdot 0$ or less at the LD50 point; (2) that, while hosts dying after inoculation with many LD 50 die as a result of the multiplication of many of the inoculated bacteria, most of those dying from 1 LD 50 or less do so following the multiplication of only one of the inoculated bacteria, regardless of the total number of bacteria inoculated. When a mixture of several equally virulent, distinguishable variants of a given pathogen are inoculated, fatal infections caused by the growth of one bacterium should result in the predominance of only one variant at post mortem. The hypotheses of maximum and of partial synergism postulate that inoculated bacteria co-operate so that the value of $p$ increases as the size of the dose increases. They predict: (1) that the slope of the dose-response curve may be more than $2 \cdot 0$ at the LD50 point; (2) that all observed fatal infections will be initiated by more than one bacterium and that consequently the inoculation of a mixed inoculum will lead to the predominance of several variants at post mortem.

Variants of Salmonella paratyphi-B which carried one of the three flagellar antigens, b, i, or e,h, were prepared by transduction. Variants of $S$. typhimurium which either fermented or did not ferment xylose were also prepared. In each case, the variants did not differ detectably in growth rate in vivo, or in virulence. The value of $b$ was 1.8 for mice inoculated with $S$. paratyphi-B by intraperitoneal injection (LD50 $=7.7 \times 10^{6}$ organisms). As predicted by the hypothesis of independent action, the relative frequencies of the variants in samples of heart blood obtained post mortem varied greatly from mouse to mouse when the dose was 1 LD50 or less, and became progressively more uniform (and similar to the inoculum) as the size of the dose increased. The value of $b$ was 0.66 for mice challenged by $S$. typhimurium by subcutaneous injection (LD50 $=2 \times 10^{3}$ organisms); and challenge with a mixed inoculum gave similar results.

Despite this general conformity with prediction, far fewer mice than expected yielded only one variant at post mortem. This discrepancy possibly resulted from

* Present address. 
a terminal breakdown in resistance, which was demonstrated by experiment. It is concluded that these results are most economically explained by the hypothesis of independent action and that this hypothesis is probably applicable to many other infective systems.

Many hosts only respond consistently to challenge by a pathogenic bacterium when the challenge dose contains many bacteria. The purpose of this paper is to discuss in general terms some possible reasons why, usually, many organisms will cause death when one organism will not, and to describe some relevant experiments. We shall consider only systems in which death is due to infection resulting from the multiplication of at least some of the inoculated organisms.

The relationship between inoculated bacteria might take one of two extreme forms. Either they could be assumed to be acting co-operatively, death being a consequence of their joint action, or they could be regarded as acting independently, more than one bacterium usually being needed because the probability of a given bacterium being lethal is less than unity (Halvorson, 1935; Druett, 1952). The situation when the LD 50 dose contains many organisms is analogous to that of a poor marksman firing at a bottle. Since his aim is poor, the bottle is unlikely to have been broken after a small number of shots has been fired but if he persists he will probably hit the bottle eventually. A local observer might be aware that the bottle was broken by the action of one bullet. On the other hand, a distant observer, informed only of the total number of shots fired before the bottle broke, would not be able to exclude the hypothesis that the breakage was due to the accumulated stresses produced by all the bullets fired.

We describe (1) the hypothesis of independent action, and (2) hypotheses of synergistic action, including the hypothesis of maximum synergism (hypothesis of the Minimal Lethal Dose) and hypotheses of partial synergism. Antagonism (interference) is not considered. The predictions of the hypotheses are first given for hosts which do not differ in resistance, not because it is thought that all hosts are the same, but because the way in which they differ is unknown. Consequently, it is impossible to make precise predictions when variation in host resistances is present. Two experiments are described which should show which hypothesis is applicable to a given system; the predicted results are given in the statement of each hypothesis. In the first experiment, the shape of the dose-response curve is determined. In the second experiment, hosts are inoculated with a mixture of recognizable variants of the same pathogen in order to estimate the number of inoculated organisms which initiate each fatal infection.

Many previous workers have pointed out that inoculated bacteria or viruses appear to act independently after inoculation. This may not be so in the last stages of a fatal infection when a pathogen may have so reduced host resistance that organisms which are normally saprophytic invade the blood stream. It is shown in the last section of the Results that a fatal infection can lead to a terminal bacteraemia by inoculated organisms which otherwise would not be present in the blood. Such a breakdown is considered to be responsible for discrepancies between prediction and observation in our experiments. 
We define $p$ as the mean probability per inoculated bacterium of multiplying to such an extent that it kills a given host (or would kill the host if it were not killed by other inoculated bacteria).

\section{The hypothesis of independent action}

This hypothesis states that $p$ is independent of $d$, the number of bacteria inoculated; i.e. the inoculated bacteria act independently, the fate of one bacterium being unaffected by the other bacteria in the inoculum. The probability of a given host surviving a dose of one bacterium is then $1-p$, the probability of surviving a dose of two organisms is $(1-p)^{2}$, and the probability of surviving a dose of $d$ organisms is $(1-p)^{d}$. We are only concerned with situations where the LD50 is a large number, in which case $d$ is large and $p$ is small. The expression $(1-p)^{d}$ is then approximately equal to the first term of the Poisson series, so that we may write

$$
S=e^{-p d},
$$

where $S$ is the probability of a given host surviving a dose of $d$ organisms and $e$ is the base of natural logarithms (Lauffer \& Price, 1945).

As $d$ is large there will be only negligible differences between the numbers of bacteria in replicate doses taken from the same suspension.

(1) The determination of the slope of the log-dose/probit-mortality curve. The hypothesis of independent action predicts that the dose-mortality relation is given by the first term of the Poisson series if the hosts do not differ in resistance, that is, if $p$ is the same for all hosts. Some curves derived in this way

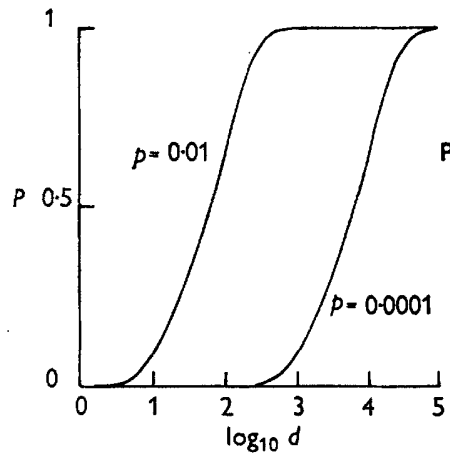

(a)

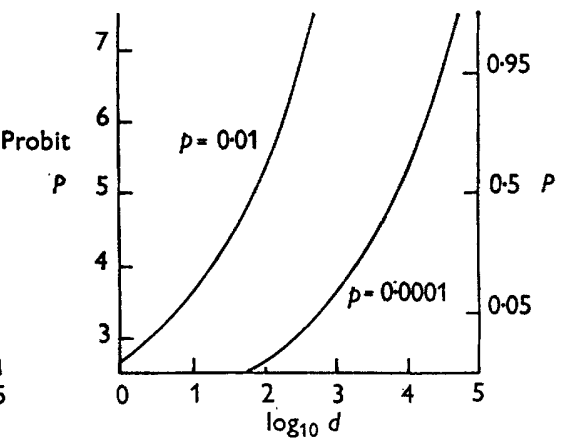

(b)

Fig. 1. $\log _{10}$-dose/mortality curves $(a)$ and $\log _{10}$-dose/probit-mortality curves (b) predicted by the hypothesis of independent action, when the hosts do not differ in resistance. $\boldsymbol{P}=$ proportion of hosts dying; $d=$ mean number of viable bacteria per dose; $p=$ mean probability per inoculated bacterium of multiplying to cause (or help to cause) a fatal infection.

are shown in Fig. $1 a$ and $b$, where $P$, the proportion of hosts killed $(=1-S)$ and probit $P$, respectively, are plotted against the logarithm of the dose $d$. It can be seen that as $p$ becomes smaller, that is, as the bacteria become less virulent, the curves shift to the right but their shapes remain the same.

It will be seen on the probit plot that, in the range of doses giving mortalities 
between 5 and $95 \%$, the curves in Fig. $1 b$ approximate to straight lines with the same slopes as those of the true curves at the LD 50 point. The term 'slope' will hereafter apply solely to the slope at the LD 50 point. Its value is 2.00 in Fig. $1 b$ (Peto, 1953). When the hosts differ in resistance, the slope will be less than 2.00. It follows that where the hypothesis of independent action is applicable, the log-dose/probit-mortality curve will have a slope of either 2 or $<2$. A slope of $>2$ would show that the theory of independent action was inapplicable.

(2) The results of challenge by a mixture of recognizable variants of the same pathogen (Kunkel, 1934; Lauffer \& Price, 1945; Zelle, Lincoln \& Young, 1946; Liu \& Henle, 1953). This test is performed as follows. Two or more variants of the selected pathogen are isolated which differ only in some stable 'marker' character unrelated to virulence. For each variant the value of $p$ and the rate of multiplication in vivo will be the same. The variants are mixed in equal proportions and hosts are challenged with graded doses of the mixture covering the range $\gg 1 \mathrm{LD} 50$ to $<1 \mathrm{LD} \mathrm{50}$. All hosts that die are sampled to determine the composition of the terminal microbial population; in our experiments, heart blood was removed from each mouse. It is assumed that the bacteria present in the sample are the descendants of those inoculated bacteria which caused the fatal infection.

When, as has been assumed, $0<p<1$, only some of the bacteria in the challenge dose will multiply to contribute to the fatal infection. The probability that none will do so is given by the first term of the Poisson series when the hosts do not differ in resistance. Similarly, the probabilities that $1,2,3, \ldots, z$ of the administered bacteria will contribute to the fatal infection are given by the 2nd, 3rd, 4th, ..., $(z+1)$ th terms of this series. The probabilities that a fatal infection resulted from 1, 2 or 3 of the inoculated bacteria are plotted in Fig. 2 against dosage measured in multiples of 1 LD 50. It can be seen that at doses $\leqslant 1$ LD 50, most of the fatally infected hosts die as a result of the multiplication of only one bacterium and each should yield a sample containing only bacteria with the same marker character. Hosts dying from the multiplication of more than one bacterium might also yield samples containing one variant, for two reasons. First, because only a small number of different variants can be used in practice so that, in a host dying as a result of the multiplication of, say, two bacteria, both bacteria might by chance carry the same marker character. Secondly, because it is unlikely that bacterial growth is synchronized in vivo and therefore one clone might produce a bacteraemia before another. It follows that the probability that a host dying from a small number of LD50 will yield a sample containing only one variant is higher than the probability that such a host will die from the multiplication of one bacterium (the latter probabilities are those given in Fig. 2).

A host dying from a dose of many LD 50 will usually do so as a result of the multiplication of many bacteria and a sample from this host should contain the descendants of $>1$ bacterium. Since in practice only a few variants are used, the sample from such a host should contain all the variants in about the same proportions as in the challenge dose. 
Since the variants are of equal virulence (i.e. have the same value of $p$ ), each has the same probability of being found in the sample from a given host dying from a small number of LD50 and each should appear with equal frequency when all the hosts are considered together.

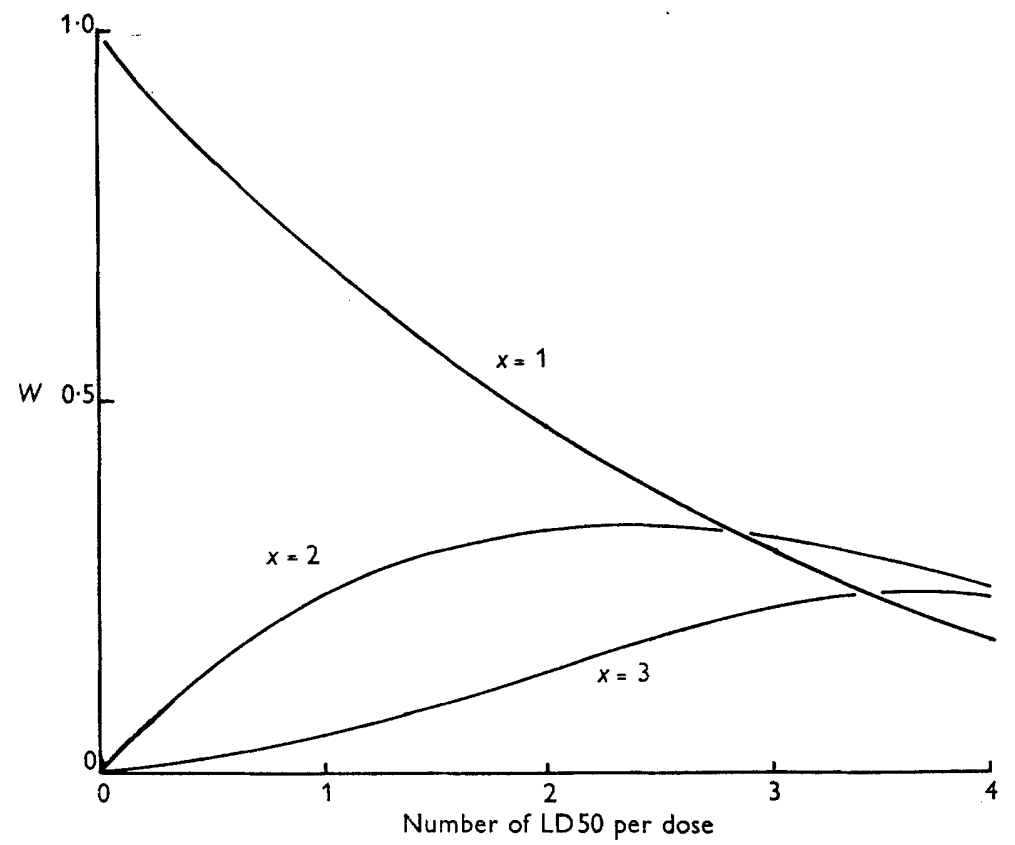

Fig. 2. Theoretical relationship between number of $\mathrm{LD} \mathrm{50}$ 's in dose and $W$, the probability that a given death resulted from the multiplication of $x$ bacteria, for $x=1, x=2$ and $x=3$. Based on the hypothesis of independent action, when the hosts do not differ in resistance.

When the hosts differ from one another in resistance to a considerable extent, the predicted compositions of the samples will differ detectably from that shown in Fig. 2, according to the distribution of resistance amongst the hosts. The host population will consist of a mixture of unusually resistant and unusually susceptible individuals with a majority of average or near average resistance. When challenged by say, 1 LD 50 dose, the more susceptible hosts will respond as if to a dose of more than $1 \mathrm{LD50}$, and will tend to yield samples containing all the variants. Conversely, when a dose of $10 \mathrm{LD} 50$ is given, the more resistant hosts will respond as if to a dose of less than 10 LD 50 and will tend to yield samples containing only one variant. The effect of variation in host resistance is therefore to increase the proportion of samples containing all the variants after challenge by small doses and to reduce the proportion after challenge by large doses.

The general prediction is, therefore, that so long as the hosts do not differ greatly in resistance, the compositions of samples from hosts challenged by large doses will be similar to that of the challenge dose and that they will differ 
increasingly from the challenge dose, and from each other, as the size of the dose becomes smaller.

It has been assumed above that the appearance of one variant only in a sample is due to chance events following challenge and not to the selection of a clone of above-average virulence. It is possible, especially with an attenuated pathogen, that mutation to increased virulence might occur before or after challenge and that the bacterial population in a sample containing only one variant was descended from such a mutant. These possibilities can be distinguished by a control experiment. The strain appearing alone in a given sample is mixed with the strains of the other variants used in the original experiment and re-inoculated in graded doses into mice by the same route. If the strain appeared by chance as postulated, it should not predominate in the samples obtained in the control experiment; but if it was a mutant of increased virulence (or a mutant with a more rapid rate of growth in vivo), it should be consistently predominant.

\section{Hypotheses of synergistic action}

Having given the predictions of the hypothesis of independent action it is necessary to consider what results these experiments would give if the bacteria did not act independently, that is, if $p$ varied with the size of the dose. We need only consider models in which synergism is assumed to occur so that $p$ increases as $d$ increases. The predictions of such models will vary according to the way in which $p$ varies with $d$. An extreme case is the hypothesis of the minimal lethal dose (MLD; Finney, 1952), which in this context we may call the hypothesis of maximum synergism. This postulates that if the number of inoculated organisms is less (even by one organism) than the MLD for a particular host, none of the inoculated bacteria will multiply to cause a fatal infection $(p=0)$ and the host will invariably survive; and that if the dose equals or exceeds the MLD all the inoculated organisms will multiply $(p=1)$ so that the host will invariably die. In this case the slope of the log-dose/probit-mortality curve is a measure of the way in which the MLD varies in the host population; it will be infinite if the hosts do not differ in resistance, and may take any value between 0 and $\infty$ if they do vary. On this model all the inoculated bacteria multiply in hosts receiving at least 1 MLD and, if they multiply in vivo at the same average rate, the sample from each dead host will contain the same proportions of variants as did the inoculum.

Models involving partial synergism can be defined in which inoculated bacteria act independently at any given dose but where $p$ increases as $d$ increases. There will then always be a chance that death will be caused by only one of the many inoculated bacteria, and the likelihood that such infections will be detected experimentally is governed by the relationship between $p$ and $d$ and by the spacing of the doses. Partial synergism can only be distinguished from complete independence if the hosts do not differ in resistance.

It is obvious that the size of the LD 50 dose might be entirely determined by the failure of most of the challenge dose to penetrate the host, as during challenge by inhalation or application to the skin. This type of system seemed 
to us less interesting than those in which the size of the LD50 is entirely governed by processes occurring within the host tissues and for this reason the only method of challenge we have used is parenteral injection. In the first set of experiments, mice were challenged by intraperitoneal injection with Salmonella paratyphi-B, a system in which the LD 50 dose (without mucin) is about $10^{7}$ bacteria. It was thus possible to use a passaged strain of maximal virulence which possessed a large LD50 value and which would be unlikely to mutate to increased virulence. The variants were prepared by transduction (Zinder \& Lederberg, 1952) and differed in their flagellar antigens which, so far as is known, have no relationship to virulence. The experiments were repeated with two variants of an attenuated strain of $S$. typhimurium given by subcutaneous injection. Although mutants of increased virulence probably might have been isolated by passage, none was encountered during the experiments. The variants of $S$. typhimurium differed in their ability to ferment xylose; the composition of the sample populations was determined by inspection of the growth on plates of indicator medium.

\section{METHODS}

Preparation of marked strains and challenge doses. An $\mathrm{O}$ strain of Salmonella paratyphi-B, SW 666, was used; this strain is a galactose non-fermenting variant of strain SW 543 described by Stocker, Zinder \& Lederberg (1953). It was first passaged three times in mice by intraperitoneal injection and from the passaged strain four $\mathbf{H}$ variants were prepared by transduction using the methods of Stocker et al. (1953). These variants were permanently fixed in phase 1 and carried the flagellar antigens e,h, $r, i$ and $b$ respectively. The first two variants were prepared using phage grown on $S$. chester $(4,5,12$ : e,h; $\mathrm{e}, \mathrm{n}, \mathrm{x})$ strain NCTC 5718, and an $\mathrm{O}$ strain of $S$. heidelberg $(4,5,12: \mathrm{r} ; 1,2$. $\mathrm{H}$ antigens known to be potentially present in the $\mathrm{O}$ strain), SL 28, respectively. The variants carrying antigens $b$ and $i$ were both obtained by treatment with a lysate of $S$.typhimurium strain TM 2 . The variant with antigen i resulted from transfer of an antigen-determining gene and a gene for flagellar production and that with antigen $b$ (the latent antigen of strain $S W 666$ ) resulted from transfer of a gene for flagellar production only. None of these variants was lysogenic for phage PLT 22 used in their preparation. In a preliminary experiment the variant with antigen $\mathbf{r}$ formed an unexpectedly small proportion in the sample populations; it was therefore discarded. The other three variants $(b, i$ and $e, h)$ were passaged in mice a further three times, passed through tubes of semi-solid agar (Craigie, 1931) and finally freeze-dried. The challenge doses were prepared as follows:

The contents of a tube containing the variant in the dried state was suspended in broth and plated on three digest agar plates which were incubated overnight at $37^{\circ}$. Next day, the growth was suspended in $1 / 4$ strength Ringer's solution and placed at $4^{\circ}$ after a portion had been taken for the estimation of the viable count. The following day, when the count was known, appropriate volumes of the suspension of each variant were mixed to give a suspension of 
known viable count containing equal proportions of the three variants. After further dilution in $1 / 4$ strength Ringer's solution, a challenge dose of $0.5 \mathrm{ml}$. was given to each mouse by intraperitoneal injection.

In the second series of experiments the variants were prepared from Salmonella typhimurium, strain SW 351, a nutritionally exacting strain which fermented neither xylose nor galactose. After repeated treatments with phage lysates of a wild-type strain of $S$. typhimurium, TM2, a series of nonexacting variants differing in their power to ferment these sugars were obtained. The $\mathrm{Xyl}^{+} \mathrm{Gal}^{-}$variant had a shorter lag phase when grown in $1 \%$ glucose peptone water than the other variants, although the exponential growth rates of the variants were the same. Therefore all challenge doses were prepared from suspensions kept in the exponential phase by the following method: Four blood agar plates, each bearing separate colonies of one variant, were stored in the refrigerator. On the first day of each experiment one colony of each variant was subcultured to one of four tubes containing $1 \%$ glucose peptone water which was incubated at $37^{\circ}$ overnight. On the second day, each culture was diluted $1 / 100$ in fresh medium and incubated at $37^{\circ}$ until it had been in the exponential phase for at least $1 \mathrm{hr}$., the rate of growth being estimated with a nephelometer. Each tube was then cooled to $10^{\circ}-15^{\circ}$ within 5 min. and then placed in the refrigerator. An exponential phase culture handled in this way is not killed and retains the ability to resume exponential growth immediately the temperature is raised to $\mathbf{3 7 ^ { \circ }}$ (Sherman \& Naylor, 1942). We have confirmed that this is true of our strain of S.typhimurium. When all the tubes had been at $4^{\circ}$ for at least $30 \mathrm{~min}$., the optical density (and inferred viable count) of each was measured. Appropriate volumes of the suspensions were then mixed to give a suspension containing equal proportions of the variants; challenge doses were prepared from this suspension by dilution in broth diluted $\mathbf{1} / 50$ in chilled distilled water. Each mouse received $\mathbf{0 . 2} \mathrm{ml}$. chilled suspension by subcutaneous injection into the area overlying the left inguinal ligament.

In preliminary experiments the two $\mathrm{Gal}^{+}$variants were found in a great preponderance in samples from mice which were dying after inoculation of mixtures of the four variants in equal parts; the $\mathrm{Gal}^{-}$variants were therefore discarded.

The challenge doses in the third set of experiments, in which mice were challenged by a mixture of Salmonella paratyphi-B and $S$. typhimurium, were prepared by the method used with $S$. paratyphi-B alone. The strain of $S$. typh $i$ murium (GLeB) was not related to the strains used in the second set of experiments.

In all experiments the viable count and composition of the challenge doses were checked by plating portions of the diluted mixed suspension to obtain separate colonies which were counted and scored.

Mice. The experiments with Salmonella paratyphi-B were performed on mice of the Webster BSVS line bred by brother-sister mating at the London School of Hygiene and Tropical Medicine. Those with $S$. typhimurium were performed on mice bred by random mating at the Postgraduate Medical School. The 
weight of the former was 18-22 g. and that of the latter was 18-25 g. All mice were kept in large glass pots, not more than five mice being placed in each pot during the experiments with $S$. typhimurium; mice were allotted at random according to the tables of Fisher \& Yates (1953).

Collection and scoring of samples. (a) Samples of heart blood. An effort was made to collect samples from mice when they were moribund rather than after death. This was difficult with mice infected by Salmonella paratyphi-B as death was not preceded by a period of visible ill health, whereas mice infected by $S$. typhimurium usually looked ill for at least $12 \mathrm{hr}$. before death.

Blood was withdrawn from the right ventricle and serially diluted in tenfold steps in either 1/4 strength Ringer's solution or 'Liquoid' broth (von Haebler \& Miles, 1938), the dilutions thereafter being stored in the refrigerator. In the experiments with Salmonella paratyphi-B, a dilution of the samples was plated on nutrient agar plates to obtain discrete colonies. These were subcultured to thick plates of nutrient agar ( $0.9 \%$ agar), incubated overnight at $\mathbf{2 2}^{\circ}$ and scored by slide-agglutination tests using specific phase 1 antisera.

Samples containing Salmonella typhimurium were inoculated by loop on to plates of indicator medium incubated overnight at $37^{\circ}$ and the colonies scored as fermenters or non-fermenters by inspection. Control experiments with mixtures containing known proportions of the variants showed that this was an accurate method, The indicator medium had the following composition: $1 / 2$ strength digest broth, $1000 \mathrm{ml}$.; xylose or galactose, $10 \mathrm{~g}$.; sodium deoxycholate, $2 \cdot 5 \mathrm{~g}$.; neutral red, $0.025 \mathrm{~g}$.

(b) Samples from abscesses. Mice surviving 3 weeks after challenge were killed by cervical dislocation. The skin overlying the abdomen was reflected and the abdominal wall seared. The abdominal cavity was opened with sterile precautions and the liver and spleen examined. Any abscesses found were removed, fresh instruments being used for each abscess, and after homogenization in a Griffith's grinder were examined in the same way as the samples of heart blood.

\section{RESULTS}

\section{Experiments with Salmonella paratyphi-B}

The LD 50 dose and the slope of the dose-mortality curve of each of the three variants (b, i and e,h) was estimated separately (Table 1 ); they did not differ significantly. The parameters of the dose-mortality curve (probit $\boldsymbol{P}$ plotted against $\log d)$ of the summed results are $\operatorname{LD50}=7 \cdot 7 \times 10^{6}(95 \%$ confidence limits, $\left.0 \cdot 48-1 \cdot 23 \times 10^{7}\right)$ with slope, $b,=1 \cdot 8(95 \%$ confidence limits : 1.1-2.5). The observed value of $b$ is therefore compatible with that derived from the hypothesis of independent action $(b \leqslant 2)$. The value of $p\left(p=0 \cdot 67 \times 10^{-7}\right.$, confidence limits, $0 \cdot 48-1 \cdot 0 \times 10^{-7}$ ) was estimated by the method given by Peto (1953).

The results of three experiments using mixed challenge doses are given in Table 2 which shows: the dose given to each group of mice; the number of mice dying; the proportion of variants present in the heart blood of each mouse; and two statistics, $\chi^{2}$ and $T$, which indicate the extent to which the heart blood 
Table 1. Mortality in mice inoculated intraperitoneally with graded doses of three variants of Salmonella paratyphi-B; each variant tested separately

\begin{tabular}{|c|c|c|c|c|c|}
\hline \multicolumn{6}{|c|}{ Variant $b$} \\
\hline$d$ & $1.62 \times 10^{8}$ & $5 \cdot 12 \times 10^{7}$ & $1.62 \times 10^{7}$ & $5 \cdot 12 \times 10^{6}$ & $1.62 \times 10^{6}$ \\
\hline $\boldsymbol{P}$ & $5 / 5$ & $4 / 5$ & $4 / 5$ & $0 / 5$ & $1 / 5$ \\
\hline \multicolumn{6}{|c|}{$\mathrm{LD} 50=1 \cdot 12 \times 10^{7} ;$ approximate confidence limits : $0 \cdot 6-3 \cdot 1 \times 10^{7}$} \\
\hline \multicolumn{6}{|c|}{ Variant $\mathbf{i}$} \\
\hline $\begin{array}{l}d \\
\boldsymbol{p}\end{array}$ & $1 \cdot 16 \times 10^{8}$ & $\begin{array}{c}3.67 \times 10^{7} \\
5 / 5\end{array}$ & $\begin{array}{c}1 \cdot 16 \times 10^{7} \\
4 / 5\end{array}$ & $\begin{array}{c}3.67 \times 10^{6} \\
2 / 5\end{array}$ & $\begin{array}{c}1.16 \times 10^{6} \\
0 / 5\end{array}$ \\
\hline
\end{tabular}

LD 50 $=0.51 \times 10^{7} ;$ approximate confidence limits : $0.32-1.7 \times 10^{7}$

\begin{tabular}{lccccc}
$d$ & \multicolumn{4}{c}{ Variant e,h } \\
$P$ & $1.42 \times 10^{8}$ & $4.49 \times 10^{7}$ & $1.42 \times 10^{7}$ & $4.49 \times 10^{6}$ & $1.42 \times 10^{6}$ \\
& $5 / 5$ & $4 / 5$ & $5 / 5$ & $0 / 5$ & $1 / 6$
\end{tabular}

$\mathrm{LD} 50=0.79 \times 10^{7}$; approximate confidence limits : $0.46-2.4 \times 10^{7}$

Difference between slopes: $\chi^{2}=1 \cdot 10: 2$ d.f. : $0.7>P>0.5$

Parameters of the dose-response curve of the summed results:

LD 50 $=7 \cdot 7 \times 10^{6}: 95 \%$ confidence limits $0.48-1.23 \times 10^{7}$.

$b=1 \cdot 81$ : s.E. $=0 \cdot 35$.

$p=0.67 \times 10^{-7}: 95 \%$ limits, $0.45-1.0 \times 10^{-7}$.

$d$ : mean number of viable bacteria per challenge dose.

$P$ : no. mice dying/no. mice inoculated (mice observed for 21 days).

samples have the same composition. Both $\chi^{2}$ and $T$ are derived from a comparison between the samples obtained from mice given the same dose. The value of $\chi^{2}$ is shown with the number of degrees of freedom (d.f.) and the associated probability of obtaining such data by sampling from homogeneous populations. The second, $T=\sqrt{ }\left\{\chi^{2} /(N \sqrt{ }\right.$ d.f. $\left.)\right\}$, is Tschuprow's coefficient of association (Kendall, 1943) which enables one to compare the degree of homogeneity of different samples regardless of the numbers of observations and of degrees of freedom in each. This coefficient ranges between 0 and 1 ; the higher the value, the greater the degree of homogeneity.

The results of the three experiments, shown in Table 2, are broadly consistent with the predictions of the hypothesis of independent action; namely, that the compositions of the samples from all mice given many LD 50 doses should be similar to that of the challenge dose; that samples from mice given smaller doses should vary in composition from mouse to mouse; and that most samples from mice given 1 or $<1$ LD 50 dose should each contain only a single variant.

It is clear from inspection in the first experiment that the samples from the 41.5 LD 50 group resemble each other more closely than do those from the mice given $4 \cdot 15$ LD 50 doses. None of the former have less than $16 \%$ of any of the variants and there is a regular tendency for variant $b$ to form a higher proportion in the samples than it did in the challenge dose. In the 4.15 LD 50 group, samples from mice 3 and 4 have only $9 \%$ of variants $i$ and $b$ respectively; variant $b$ does not regularly predominate and either e,h (nos. 1, 4 and 7) or i (no. 2) may predominate in some mice. Finally, the pair of samples from the 
Table 2. Mixed-inoculum experiments with Salmonella paratyphi-B: proportion of variants found in post-mortem blood of mice dying after intraperitoneal inoculation of a mixture of three variants

\begin{tabular}{|c|c|c|c|c|c|c|c|c|c|c|c|}
\hline \multirow{2}{*}{$\overbrace{\begin{array}{c}\text { No. viable } \\
\text { bacteria }\end{array}}^{\text {Dose }}$} & \multirow[b]{2}{*}{ LD 50} & \multirow{2}{*}{$\begin{array}{l}\text { Mortality } \\
\text { (deaths/no. } \\
\text { inoculated) }\end{array}$} & \multirow[b]{2}{*}{$\begin{array}{l}\text { Mouse } \\
\text { no. }\end{array}$} & \multicolumn{3}{|c|}{$\begin{array}{l}\text { Proportion of variant } \\
\text { in post-mortem blood }\end{array}$} & \multirow{2}{*}{$\begin{array}{l}\text { No. } \\
\text { colo- } \\
\text { nies } \\
\text { scored }\end{array}$} & \multirow[b]{2}{*}{$\chi^{2}$} & \multirow[b]{2}{*}{ d.f. } & \multirow[b]{2}{*}{$\boldsymbol{P}$} & \multirow[b]{2}{*}{$T$} \\
\hline & & & & $\mathbf{b}$ & $\gamma_{i}$ & $\overrightarrow{\mathrm{e}, \mathrm{h}}$ & & & & & \\
\hline \multicolumn{12}{|c|}{ Experiment 1} \\
\hline \multirow{5}{*}{$3.2 \times 10^{8}$} & \multirow{5}{*}{$4.1 \cdot 5$} & \multirow{5}{*}{$5 / 5$} & (Inoculum & 0.37 & $0 \cdot 30$ & 0.33 & 97) & \multirow{5}{*}{$11 \cdot 5$} & \multirow{5}{*}{8} & \multirow{4}{*}{$\begin{array}{l}>0 \cdot 1 \\
<0.2\end{array}$} & \multirow{5}{*}{$0 \cdot 120$} \\
\hline & & & $\begin{array}{l}1 \\
2\end{array}$ & $\begin{array}{l}0.53 \\
0.55\end{array}$ & $\begin{array}{l}0 \cdot 26 \\
0 \cdot 16\end{array}$ & $\begin{array}{l}0 \cdot 21 \\
0 \cdot 29\end{array}$ & $\left.\begin{array}{l}38 \\
64\end{array}\right)$ & & & & \\
\hline & & & 3 & 0.52 & 0.27 & 0.21 & 46 & & & & \\
\hline & & & 4 & 0.65 & $0 \cdot 18$ & $0 \cdot 17$ & 98 & & & & \\
\hline & & & 5 & 0.40 & $0 \cdot 30$ & $0 \cdot 30$ & 37 & & & & \\
\hline \multirow{8}{*}{$3.2 \times 10^{7}$} & \multirow{8}{*}{$4 \cdot 15$} & \multirow{8}{*}{$8 / 8$} & 1 & $0 \cdot 33$ & $0 \cdot 16$ & 0.51 & $63)$ & \multirow{8}{*}{$68 \cdot 3$} & \multirow{7}{*}{12} & & \\
\hline & & & 2 & $0 \cdot 28$ & $0 \cdot 39$ & $\mathbf{0} \cdot 33$ & 33 & & & & \\
\hline & & & 3 & $0 \cdot 62$ & 0.09 & $0 \cdot 29$ & 33 & & & & \\
\hline & & & 4 & 0.09 & 0.25 & $0 \cdot 66$ & 67 & & & $<0.001$ & 0.236 \\
\hline & & & $\mathbf{5}$ & $0 \cdot 60$ & $0 \cdot 20$ & $0 \cdot 20$ & 35 & & & & \\
\hline & & & 6 & $0 \cdot 56$ & 0.21 & 0.23 & 52 & & & & \\
\hline & & & 7 & $0 \cdot 30$ & $0 \cdot 19$ & $0 \cdot 51$ & 37) & & & & \\
\hline & & & 8 & & t scor & & & & & & \\
\hline $1.6 \times 10^{7}$ & $2 \cdot 07$ & $3 / 8$ & $\begin{array}{l}1^{*} \\
2\end{array}$ & $\begin{array}{l}0 \\
0 \cdot 26\end{array}$ & $\begin{array}{l}0 \\
0 \cdot 24\end{array}$ & $\begin{array}{l}1 \cdot 0 \\
0 \cdot 50\end{array}$ & $\left.\begin{array}{r}101 \\
34\end{array}\right\}$ & $57 \cdot 8$ & 2 & $<0.001$ & 0.550 \\
\hline & & & 3 & & t scor & & & & & & \\
\hline & & & & Expe & ment 2 & & & & • & & \\
\hline & & & (Inoculum & 0.35 & $\mathbf{0} \cdot \mathbf{3 3}$ & $0 \cdot 32$ & 120) & & & & \\
\hline & & & 1 & 0.33 & 0.23 & 0.44 & $30)$ & & & & \\
\hline & & & 2 & $0 \cdot 33$ & $0 \cdot 30$ & $0 \cdot 37$ & 30 & & & & \\
\hline $1.54 \times 10^{9}$ & 200 & $5 / 5$ & $\mathbf{3}$ & 0.33 & $0 \cdot 17$ & 0.50 & 30 & $4 \cdot 6$ & 8 & $<0.8$ & $0 \cdot 105$ \\
\hline & & & 4 & $\mathbf{0} \cdot 30$ & $0 \cdot 37$ & $0 \cdot 33$ & 30 & & & $>0.7$ & \\
\hline & & & $\mathbf{5}$ & $0 \cdot 23$ & $0 \cdot 30$ & 0.47 & 30J & & & & \\
\hline & & & 1 & 0.37 & $0 \cdot 16$ & 0.47 & 30 ) & & & & \\
\hline & & & 2 & $0 \cdot 20$ & $0 \cdot 17$ & 0.63 & 30 & & & & \\
\hline $7 \cdot 7 \times 10^{8}$ & 100 & $5 / 5$ & 3 & 0.47 & $0 \cdot 13$ & 0.40 & 30 & $13 \cdot 3$ & 8 & 0.1 & 0.177 \\
\hline & & & 4 & 0.44 & $0 \cdot 33$ & $0 \cdot 23$ & 30 & & & & \\
\hline & & & $\mathbf{5}$ & $0 \cdot 30$ & $0 \cdot 20$ & 0.50 & 30」 & & & & \\
\hline & & & 1 & 0.27 & 0.4 .0 & 0.33 & $30)$ & & & & \\
\hline & & & 2 & $0 \cdot 27$ & $0 \cdot 17$ & 0.56 & 30 & & & & \\
\hline $3.85 \times 10^{8}$ & 50 & $\mathbf{5} / \mathbf{5}$ & 3 & 0.57 & $0 \cdot 13$ & 0.30 & 30 & $6 \cdot 3$ & 8 & $<0.7$ & 0.122 \\
\hline & & & 4 & $0 \cdot 27$ & $0 \cdot 13$ & $0 \cdot 60$ & 30 & & & $>0.5$ & \\
\hline & & & $\mathbf{5}$ & $0 \cdot 30$ & $0 \cdot 13$ & 0.57 & $30 J$ & & & & \\
\hline & & & 1 & $0 \cdot 33$ & 0.07 & 0.60 & $30)$ & & & & \\
\hline & & & 2 & 0.23 & 0.33 & $0 \cdot 44$ & 30 & & & & \\
\hline $1.92 \times 10^{8}$ & 25 & $5 / 5$ & 3 & 0.44 & $0 \cdot 23$ & $\mathbf{0} \cdot \mathbf{3 3}$ & 30 & $19 \cdot 1$ & 8 & $<0.02$ & 0.212 \\
\hline & & & 4 & $0 \cdot 13$ & $0 \cdot 13$ & 0.74 & 30 & & & $>0.01$ & \\
\hline & & & 5 & $0 \cdot 17$ & $0 \cdot 20$ & $0 \cdot 63$ & 30J & & & & \\
\hline
\end{tabular}


Table 2 (cont.)

\begin{tabular}{|c|c|c|c|c|c|c|c|c|c|c|c|}
\hline \multirow{2}{*}{$\overbrace{\begin{array}{c}\text { No. viable } \\
\text { bacteria } I\end{array}}^{\text {Dose }}$} & $\stackrel{e}{e}$ & \multirow{2}{*}{$\begin{array}{l}\text { Mortality } \\
\text { (deaths/no. } \\
\text { inoculated) }\end{array}$} & \multirow[b]{2}{*}{$\begin{array}{c}\text { Mouse } \\
\text { no. }\end{array}$} & \multicolumn{3}{|c|}{$\begin{array}{l}\text { Proportion of variant } \\
\text { in post-mortem blood }\end{array}$} & \multirow{2}{*}{$\begin{array}{l}\text { No. } \\
\text { colo- } \\
\text { nies } \\
\text { scored }\end{array}$} & \multirow[b]{2}{*}{$\chi^{2}$} & \multirow[b]{2}{*}{ d.f. } & \multirow[b]{2}{*}{$\boldsymbol{P}$} & \multirow[b]{2}{*}{$\boldsymbol{T}$} \\
\hline & LD 50 & & & $\mathbf{b}$ & $\overbrace{i}^{i}$ & $\overline{\mathrm{e}, \mathrm{h}}$ & & & & & \\
\hline $1.54 \times 10^{7}$ & 2 & $10 / 10$ & $\begin{array}{r}1 \\
2 \\
3 \\
4 \\
5 \\
6 \\
7 \\
8 \\
9 \\
10\end{array}$ & $\begin{array}{l}0 \cdot 20 \\
0 \cdot 10 \\
0 \cdot 40 \\
0 \cdot 26 \\
0 \cdot 33 \\
0 \cdot 37 \\
0 \cdot 17 \\
0 \cdot 30 \\
0 \cdot 17 \\
0\end{array}$ & $\begin{array}{l}0 \cdot 23 \\
0 \cdot 17 \\
0 \cdot 27 \\
0 \cdot 30 \\
0 \cdot 37 \\
0 \cdot 30 \\
0 \cdot 56 \\
0 \cdot 20 \\
0 \cdot 17 \\
0 \cdot 87\end{array}$ & $\begin{array}{l}0.57 \\
0 \cdot 73 \\
0 \cdot 33 \\
0 \cdot 44 \\
0 \cdot 30 \\
0 \cdot 33 \\
0 \cdot 27 \\
0 \cdot 50 \\
0 \cdot 66 \\
0 \cdot 13\end{array}$ & $\left.\begin{array}{l}\mathbf{3 0} \\
\mathbf{3 0} \\
\mathbf{3 0} \\
\mathbf{3 0} \\
\mathbf{3 0} \\
\mathbf{3 0} \\
\mathbf{3 0} \\
\mathbf{3 0} \\
\mathbf{3 0} \\
\mathbf{3 0}\end{array}\right\}$ & $69 \cdot 5$ & 18 & $<0.001$ & 0.234 \\
\hline $7 \cdot 7 \times 10^{6}$ & 1 & $6 / 10$ & $\begin{array}{l}1 \\
3 \\
6 \\
7 \\
8 \\
9\end{array}$ & $\begin{array}{c}0.20 \\
0 \cdot 13 \\
0.20 \\
0 \cdot 04 \\
0.24\end{array}$ & $\begin{array}{c}0 \cdot 23 \\
0 \cdot 13 \\
0 \cdot 33 \\
0 \cdot 09 \\
0 \cdot 15 \\
\text { t scor }\end{array}$ & $\begin{array}{l}0.57 \\
0 \cdot 74 \\
0.47 \\
0 \cdot 87 \\
0.61\end{array}$ & $\left.\begin{array}{l}30 \\
30 \\
30 \\
56 \\
75\end{array}\right\}$ & $23 \cdot 5$ & 8 & $\begin{array}{l}<0.01 \\
>0.001\end{array}$ & $0 \cdot 194$ \\
\hline $3 \cdot 85 \times 10^{6}$ & $0 \cdot 5$ & $2 / 10$ & $\begin{array}{l}4 \\
5\end{array}$ & $\begin{array}{l}0.83 \\
0.02\end{array}$ & $\begin{array}{l}0 \\
0\end{array}$ & $\begin{array}{l}0 \cdot 17 \\
0 \cdot 98\end{array}$ & $\left.\begin{array}{l}64 \\
62\end{array}\right\}$ & $84 \cdot 8$ & 1 & $<0.001$ & $0 \cdot 82$ \\
\hline & & & (Inoculum & Ex & $\begin{array}{l}\text { iment } \\
\text { t scor }\end{array}$ & & & & & & \\
\hline $6.16 \times 10^{7}$ & 8 & $5 / 5$ & $\begin{array}{l}1 \\
\mathbf{2} \\
\mathbf{3} \\
4 \\
\mathbf{5}\end{array}$ & $\begin{array}{l}0.59 \\
0.40 \\
0.66 \\
0.54 \\
0.22\end{array}$ & $\begin{array}{l}0 \cdot 14 \\
0 \cdot 33 \\
0 \cdot 18 \\
0 \cdot 24 \\
0 \cdot 12\end{array}$ & $\begin{array}{l}0 \cdot 27 \\
0 \cdot 27 \\
0 \cdot 16 \\
0 \cdot 22 \\
0 \cdot 66\end{array}$ & $\left.\begin{array}{l}22 \\
30 \\
50 \\
50 \\
41\end{array}\right\}$ & $36 \cdot 4$ & 8 & $<0.001$ & 0.258 \\
\hline $7.7 \times 10^{6}$ & $\mathbf{1}$ & $6 / 10$ & $\begin{array}{l}1 \\
2 \\
3 \\
4 \\
5 \\
6\end{array}$ & $\begin{array}{l}0.22 \\
0.53 \\
0.29 \\
0.50 \\
0.02\end{array}$ & $\begin{array}{c}0.50 \\
0 \cdot 22 \\
0 \cdot 39 \\
0 \cdot 16 \\
0 \cdot 96 \\
\text { t scor }\end{array}$ & $\begin{array}{l}0 \cdot 28 \\
0 \cdot 25 \\
0 \cdot 32 \\
0 \cdot 34 \\
0 \cdot 02\end{array}$ & $\left.\begin{array}{l}36 \\
36 \\
31 \\
36 \\
99\end{array}\right\}$ & 116 & 8 & $<0.001$ & 0.413 \\
\hline $3.85 \times 10^{6}$ & 0.5 & $3 / 10$ & $\begin{array}{l}1 \\
2 \\
\mathbf{3}\end{array}$ & $\begin{array}{l}0 \cdot 36 \\
0 \cdot 04 \\
0\end{array}$ & $\begin{array}{l}0 \cdot 36 \\
0 \cdot 81 \\
0\end{array}$ & $\begin{array}{l}0 \cdot 28 \\
0 \cdot 15 \\
1 \cdot 0\end{array}$ & $\left.\begin{array}{r}34 \\
123 \\
40\end{array}\right\}$ & 134 & 4 & $<0.001$ & 0.584 \\
\hline $1.92 \times 10^{6}$ & $0 \cdot 25$ & $1 / 10$ & 1 & 0.05 & 0.01 & 0.94 & 131 & - & - & - & - \\
\hline
\end{tabular}

$T$ is Tschuprow's coefficient of variation; $T=\sqrt{ }\left[\left(\chi^{2} / N \sqrt{ }\right.\right.$ d.f. $\left.)\right]$. The values of $\chi^{2}$ and of $T$ are derived from comparisons between mice in each dose group.

* The inoculum mixture for Expt. 2 comprised the stock strains of variants $b$ and $i$, combined with the e,h variant recovered in pure culture from mouse no. 1 of the group given 2.07 LD 50 in Expt. 1.

2.07 LD 50 group are even more heterogeneous owing to sample 1 containing only variant $i$ in 101 colonies tested.

The strain of variant e,h isolated in pure culture from the first mouse of the 2.07 LD 50 group was then combined with original strains of variants $b$ and $i$ to prepare the challenge dose for Expt. 2, to test if it was a mutant of increased virulence or faster growth rate.

The results of Expt. 2 are similar to those of Expt. 1. Since variant e, h did 
not regularly predominate, it was concluded that the strain isolated in Expt. 1 was not a mutant. For reasons given in the Discussion, we consider that the predictions of the theory of independent action are only tested by doses of Salmonella paratyphi-B $\leqslant \mathbf{2}$ LD 50; nevertheless, the results with the higher doses used in this experiment show that the variants grew at the same rate in hosts whose resistance may, however, have been reduced by the large number of bacteria administered. Four samples from mice given lower doses contained over $80 \%$ of one variant (2 LD 50, no. 10; 1 LD 50, no. 7; 0.5 LD 50, nos. 4 and 5). No samples containing only one variant were encountered.

The highest dose given in the third experiment was 8 LD 50. One sample contained only one variant (0.5 LD 50, no. 3, 40 colonies scored) and three contained a preponderance of one variant ( 1 LD 50, no. 5; 0.5 LD 50, no. 2 and $0 \cdot 25$ LD 50, no. 1).

The survivors in all experiments were killed 3 weeks after challenge and any isolated abscesses in the liver and spleen were removed and examined with the results shown in Table 3. Abscesses were rarely found in the spleen. Macroscopically normal liver was usually almost sterile; it is suspected that the exceptional specimen (Expt. 3, mouse $b$ ) contained a hidden abscess. Most abscesses contained about $10^{6}$ viable bacteria composed in most cases of either a majority of or only one variant. One mouse (Expt. 1, no. 5) yielded ten abscesses of which eight contained a majority of variant $i$ and one a majority of variant $b$, the observations on the remaining abscess (no. 9) being of little value because it was almost sterile and only three colonies were obtained.

\section{Experiments with Salmonella typhimurium}

As has been seen, the experiments with Salmonella paratyphi-B yielded fewer samples containing one variant than had been predicted from the hypothesis of independent action. We suspected that this was due to the effect of a terminal breakdown in resistance, caused by the bacteria initiating the fatal infection, which encouraged the multiplication of other bacteria to such an extent that they appeared in the sample. We supposed that this would be less likely to occur with a pathogen with a smaller LD50 dose than that of $S$. paratyphi-B. The experiment was therefore repeated using $S$. typhimurium administered to mice by subcutaneous injection.

Table 4 gives the observations from which were computed the parameters of the dose-mortality curves of the $\mathrm{Xyl}^{+} \mathrm{Gal}^{+}$and $\mathrm{Xyl}^{-} \mathrm{Gal}^{+}$variants. These curves did not differ significantly when analysed by probit methods. The LD 50 doses were $10^{3 \cdot 13}$ and $10^{3.42}$, the difference in log LD 50 being $0.29(95 \%$ confidence limits of -0.66 to $+1 \cdot 38$ ) which was not significant, nor was there a significant difference in their slopes $\left(\chi^{2}=2.9\right.$ on 1 d.f.; $\left.P=0.09\right)$. The mice clearly differed in resistance to a considerable extent for the common slope was $0.66(95 \%$ confidence limits : $0 \cdot 34-0.98)$ which is significantly less than 2 . For this reason it was not expected that samples containing one variant only would be encountered as predicted from the Poisson series in the case when the hosts did not differ in resistance. Nevertheless, the compositions of the 
Table 3. Mixed-inoculum experiments with Salmonella paratyphi-B: proportion of variants found in liver-abscesses, and in macroscopically normal liver, of mice surviving inoculation of a mixture of three variants

In Expts. 1-3 (Table 2) mice surviving 21 days after inoculation were killed. Any liver abscesses seen were dissected out and cultured; portions of apparently normal liver were also cultured from some mice with abscesses.

Source of mouse (Table 2)

\begin{tabular}{|c|c|c|c|c|c|c|c|c|}
\hline 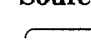 & 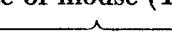 & & & Viable & 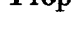 & specir & $a$ & \\
\hline $\begin{array}{c}\text { Expt. } \\
\text { no. }\end{array}$ & Dose group & $\begin{array}{c}\text { Mouse } \\
\text { no. }\end{array}$ & Specimen & $\begin{array}{l}\text { bacteria/ } \\
\text { specimen }\end{array}$ & $\mathbf{b}$ & $\mathbf{i}$ & $\mathbf{e}, \mathbf{h}$ & $\begin{array}{c}\text { colonies } \\
\text { tested }\end{array}$ \\
\hline 1 & 2.1 LD50 & 5 & $\left\{\begin{array}{l}\text { Abscess 1 } \\
\text { Abscess 2 } \\
\text { Abscess 3 } \\
\text { Abscess 4 } \\
\text { Abscess 5 } \\
\text { Abscess 6 } \\
\text { Abscess 7 } \\
\text { Abscess 8 } \\
\text { Abscess 9 } \\
\text { Abscess 10 }\end{array}\right.$ & $\begin{array}{l}\text { ND } \\
\text { ND } \\
\text { ND } \\
\text { ND } \\
\text { ND } \\
\text { ND } \\
\text { ND } \\
\text { ND } \\
\text { ND } \\
\text { ND }\end{array}$ & $\begin{array}{l}0 \cdot 17 \\
0 \cdot 04 \\
0 \cdot 05 \\
0 \\
0 \cdot 13 \\
0 \\
0 \cdot 10 \\
0 \cdot 20 \\
1 \cdot 0 \\
0 \cdot 90\end{array}$ & $\begin{array}{l}0 \cdot 63 \\
0 \cdot 67 \\
0 \cdot 95 \\
1 \cdot 0 \\
0 \cdot 84 \\
1 \cdot 0 \\
0 \cdot 90 \\
0 \cdot 80 \\
0 \\
0\end{array}$ & $\begin{array}{l}0 \cdot 20 \\
0 \cdot 29 \\
0 \\
0 \\
0 \cdot 03 \\
0 \\
0 \\
0 \\
0 \\
0 \cdot 10\end{array}$ & $\begin{array}{r}35 \\
27 \\
61 \\
40 \\
32 \\
20 \\
20 \\
20 \\
3 \\
20\end{array}$ \\
\hline 1 & 2.1 LD50 & 6 & Abscess & ND & $0 \cdot 84$ & $0 \cdot 16$ & $\mathbf{0}$ & 38 \\
\hline 1 & $1 \mathrm{LD50}$ & 1 & Abscess & ND & $\mathbf{0}$ & $1 \cdot 0$ & 0 & $\mathbf{5 0}$ \\
\hline 3 & $2 \operatorname{LD} 50$ & a* & $\left\{\begin{array}{l}\text { Abscess } \\
\text { Liver }\end{array}\right.$ & $\begin{array}{c}1.6 \times 10^{6} \\
0\end{array}$ & $\begin{array}{c}0.54 \\
-\end{array}$ & $\begin{array}{c}0.46 \\
-\end{array}$ & 0 & 39 \\
\hline 3 & 2 LD 50 & $\mathrm{~b}^{*}$ & $\left\{\begin{array}{l}\text { Abscess } \\
\text { Liver }\end{array}\right.$ & $\begin{array}{r}1.65 \times 10^{6} \\
3.9 \times 10^{5}\end{array}$ & $\begin{array}{l}0 \cdot 97 \\
0\end{array}$ & $\begin{array}{l}0.03 \\
0 \cdot 14\end{array}$ & $\begin{array}{l}0 \\
0.86\end{array}$ & $\begin{array}{l}36 \\
36\end{array}$ \\
\hline $\mathbf{3}$ & 1 LD 50 & $\mathrm{c}^{*}$ & $\left\{\begin{array}{l}\text { Abscess } \\
\text { Liver }\end{array}\right.$ & $\begin{array}{l}3.6 \times 10^{5} \\
1.5 \times 10^{2}\end{array}$ & $\begin{array}{l}1 \cdot 0 \\
0 \cdot 20\end{array}$ & $\begin{array}{l}0 \\
0 \cdot 33\end{array}$ & $\begin{array}{l}0 \\
0.47\end{array}$ & $\begin{array}{l}39 \\
15\end{array}$ \\
\hline 3 & 1 LD 50 & d* & $\left\{\begin{array}{l}\text { Abscess 1 } \\
\text { Abscess 2 } \\
\text { Abscess 3 } \\
\text { Liver }\end{array}\right.$ & $\begin{array}{c}1 \cdot 75 \times 10^{6} \\
9 \cdot 4 \times 10^{5} \\
9 \cdot 5 \times 10^{5} \\
10^{2}\end{array}$ & $\begin{array}{l}0 \cdot 20 \\
0 \cdot 62 \\
0 \\
0\end{array}$ & $\begin{array}{l}0 \cdot 77 \\
0 \cdot 16 \\
1 \cdot 0 \\
0\end{array}$ & $\begin{array}{l}0 \cdot 03 \\
0 \cdot 24 \\
0 \\
1 \cdot 0\end{array}$ & $\begin{array}{r}\mathbf{3 9} \\
\mathbf{3 4} \\
\mathbf{3 6} \\
\mathbf{4}\end{array}$ \\
\hline
\end{tabular}

* Mice a, b, c and d were survivors from a subsidiary part of Expt. 3, not recorded in Table 2: the groups of mice concerned received the same inocula as the groups shown in Table 2, but in mice which died post-mortem blood was not cultured to determine the proportion of variants.

ND: viable count not done.

Table 4. Mortality in mice inoculated intraperitoneally with graded doses of two variants of Salmonella typhimurium; each variant tested separately

\begin{tabular}{|c|c|c|c|c|c|c|c|}
\hline \multicolumn{8}{|c|}{$\mathrm{Xyl}^{+} \mathrm{Gal}^{+}$variant } \\
\hline$d$ & $6 \times 10^{4}$ & $2 \times 10^{4}$ & $6.6 \times 10^{8}$ & $2.2 \times 10^{3}$ & $7 \cdot 3 \times 10^{2}$ & $2.4 \times 10^{2}$ & $8 \times 10^{1}$ \\
\hline $\boldsymbol{P}$ & $6 / 6$ & $6 / 6$ & $3 / 6$ & $4 / 6$ & $3 / 6$ & $3 / 6$ & $1 / 6$ \\
\hline \multicolumn{8}{|c|}{$\mathrm{LD} \mathrm{50}=2.6 \times 10^{3}$} \\
\hline \multicolumn{8}{|c|}{ Xyl- Gal+ variant } \\
\hline$d$ & $5.6 \times 10^{4}$ & $1.9 \times 10^{4}$ & $6 \cdot 3 \times 10^{3}$ & $2 \cdot 1 \times 10^{3}$ & $7 \times 10^{2}$ & $2 \cdot 3 \times 10^{2}$ & $7 \cdot 6 \times 10^{1}$ \\
\hline $\boldsymbol{P}$ & $6 / 6$ & $3 / 6$ & $5 / 6$ & $2 / 6$ & $1 / 6$ & $2 / 6$ & $1 / 6$ \\
\hline \multicolumn{8}{|c|}{$\mathrm{LD} 50=1.3 \times 10^{3}$} \\
\hline
\end{tabular}

Difference in $\log _{10} \mathrm{LD50}=\mathbf{0 \cdot 2 9}(95 \%$ confidence limits $:-0 \cdot 66$ to $+1 \cdot 38)$.

Slope of the summed dose-mortality curves $=0.66$ (95\% confidence limits : $0 \cdot 34$ to 0.98 ). $d$ : mean number of viable bacteria per challenge dose.

$P$ : no. mice dying/no. mice challenged (mice observed for 21 days). 
samples should have become increasingly heterogeneous as the size of the dose decreased if the hypothesis of independent action was applicable.

Fig. 3 shows the result of one experiment in which mice were challenged with a mixture of the $\mathrm{Xyl}^{+} \mathrm{Gal}^{+}$and $\mathrm{Xyl}^{-} \mathrm{Gal}^{+}$variants. The proportion of $\mathrm{Xyl}^{+}$colonies in each sample is shown on the ordinate and the dose is given on the abscissa. Between 90 and 400 colonies were scored from each sample

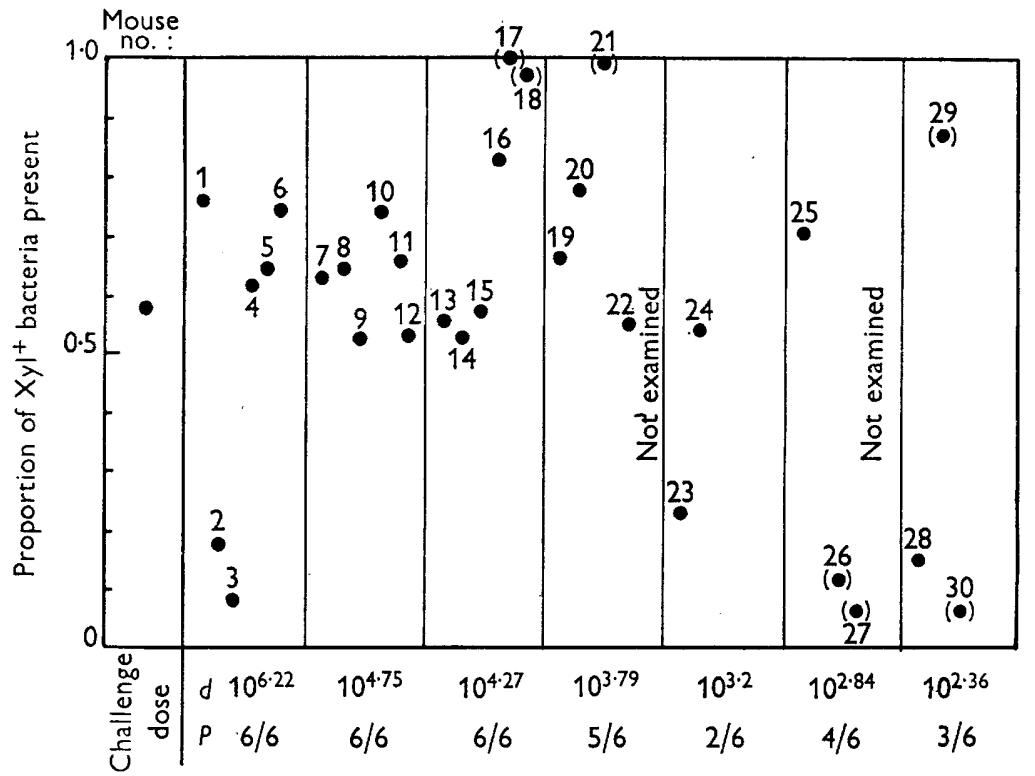

Fig. 3. Proportion of $\mathrm{Xyl}^{+}$bacteria in samples of post-mortem heart blood of mice dying after inoculation of graded doses of a mixture of a Xyl ${ }^{+}$and a Xyl- variant of Salmonella typhimurium. Each dot represents the proportion of the $\mathrm{Xyl}^{+}$variant found in blood from a given mouse (the composition of the inoculum is shown on the left). The recovered strains marked by brackets were tested in the control experiment recorded in Table 5 . $d$ : mean number of viable organisms per dose; $P$ : number of mice dying/number of mice challenged.

except in five samples where the numbers were $71,65,34,84$ and 66 . The results resemble those obtained with Salmonella paratyphi-B; the samples differ increasingly as the size of the dose becomes smaller. Also, samples were again encountered which had a great preponderance of one variant but fewer than expected contained only one variant. Each preponderant strain, from mice marked by brackets in Fig. 3, was recombined with the original strain of the alternative type and injected into four mice subcutaneously in a dose of $3.2 \times 10^{5}$ bacteria (about 100 LD 50 doses) to detect mutants. The results are given in Table 5 and show that a strain which was predominant in the original experiment never consistently predominated in the control experiment. Therefore these strains were not mutants. It is unfortunate that the variants from samples nos. 2 and 3 in the group given $10^{6.22}$ bacteria were not tested in this way, for these might well have been mutants. It can be seen that the samples in each group in the control experiment were heterogeneous. (The values of 
Table 5. Mixed-inoculum experiments with Salmonella typhimurium: control experiments on strains recovered, as predominant strains, from mice dying after inoculation of a mixture of two variants (Fig. 3)

The predominant strain $\left(\mathrm{Xyl}^{+}\right.$or $\left.\mathrm{Xyl}^{-}\right)$was recovered irom each mouse marked with brackets in Fig. 3 and was mixed in equal proportions with the stock strain of the opposite $\mathrm{Xyl}$ character; each mixture was inoculated subcutaneously into four mice (dose $c .3 \times 10^{5}$ bacteria $=c .100$ LD 50). Post-mortem heart blood from these mice was plated to determine the proportion of the variants; each inoculum mixture was similarly plated.

Recovered strain

\begin{tabular}{|c|c|c|c|c|c|c|c|c|c|}
\hline \multirow{2}{*}{$\begin{array}{c}\text { Source: } \\
\text { Fig. 3, } \\
\text { mouse } \\
\text { no. }\end{array}$} & \multirow{2}{*}{$\begin{array}{c}\text { Xyl } \\
\text { character }\end{array}$} & \multirow{2}{*}{$\begin{array}{c}\text { Mouse } \\
\text { no. }\end{array}$} & \multicolumn{2}{|c|}{$\begin{array}{l}\text { Proportion of } \\
\text { variants in post- } \\
\text { mortem blood }\end{array}$} & \multirow{2}{*}{$\begin{array}{l}\text { No. } \\
\text { colonies } \\
\text { scored }\end{array}$} & \multirow[b]{2}{*}{$\chi^{2}$} & \multirow[b]{2}{*}{ d.f. } & \multirow[b]{2}{*}{$\boldsymbol{P}$} & \multirow[b]{2}{*}{$T$} \\
\hline & & & $\mathrm{Xyl}^{+}$ & $\mathrm{Xyl}^{-}$ & & & & & \\
\hline \multirow{5}{*}{17} & \multirow{4}{*}{$\mathbf{X y l}+$} & (Inoculum & 0.58 & $0 \cdot 42$ & 136) & \multirow{4}{*}{$210 \cdot 5$} & \multirow{5}{*}{$\mathbf{3}$} & \multirow{5}{*}{$<0.001$} & \multirow{4}{*}{0.515} \\
\hline & & 1 & 0.57 & 0.43 & 89 & & & & \\
\hline & & 2 & 0.93 & $0 \cdot 07$ & 111 & & & & \\
\hline & & 3 & $\begin{array}{l}1.0 \\
0.70\end{array}$ & 0 & 150 & & & & \\
\hline & \multirow{5}{*}{$\mathbf{X y l +}$} & $\begin{array}{l}4 \\
4\end{array}$ & 0.79 & $0 \cdot 21$ & 109) & & & & \multirow{5}{*}{0.455} \\
\hline \multirow{4}{*}{18} & & $\int_{\mathbf{I}}^{\text {(Inoculum }}$ & $\begin{array}{l}0 \cdot 62 \\
0 \cdot 80\end{array}$ & $\begin{array}{l}0 \cdot 38 \\
0 \cdot 20\end{array}$ & $\begin{array}{l}103) \\
189\end{array}$ & \multirow{4}{*}{$171 \cdot 5$} & \multirow{4}{*}{3} & \multirow{4}{*}{$<0.001$} & \\
\hline & & 2 & $0 \cdot 11$ & $0 \cdot 89$ & 126 & & & & \\
\hline & & 3 & $0 \cdot 49$ & 0.51 & 100 & & & & \\
\hline & & 4 & $0 \cdot 90$ & $0 \cdot 10$ & 63) & & & & \\
\hline \multirow{5}{*}{21} & \multirow{5}{*}{$\mathbf{X y l}{ }^{+}$} & (Inoculum & $0 \cdot 67$ & $0 \cdot 33$ & 85) & \multirow{5}{*}{$110 \cdot 3$} & & & \\
\hline & & 1 & 0.74 & $0 \cdot 26$ & 84 & & & & \\
\hline & & 2 & $0 \cdot 64$ & $0 \cdot 36$ & 184 & & & & \\
\hline & & 3 & $0 \cdot 79$ & $0 \cdot 21$ & 159 & & 3 & $<0.001$ & $0 \cdot 350$ \\
\hline & & 4 & $0 \cdot 15$ & 0.85 & 92) & & & & \\
\hline & & (Inoculum & 0.56 & 0.44 & 92) & & & & \\
\hline & & $\mathbf{1}$ & $0 \cdot 70$ & $0 \cdot 30$ & 139 & & & & \\
\hline 26 & Xyl- & 2 & $1 \cdot 0$ & $\mathbf{0}$ & 110 & & & & \\
\hline & & $\mathbf{3}$ & 0.74 & $0 \cdot 26$ & 232 & $58 \cdot 7$ & 3 & $<0.001$ & $0 \cdot 229$ \\
\hline & & 4 & 0.59 & $0 \cdot 41$ & 110 & & & & \\
\hline & & (Inoculum & 0.56 & 0.44 & 92) & & & & \\
\hline & & $\mathbf{1}$ & 0.75 & 0.25 & $261)$ & & & & \\
\hline 27 & Xyl- & 2 & 0.56 & $0 \cdot 44$ & 220 & & & & \\
\hline & & 3 & 0.51 & 0.49 & 118 & $48 \cdot 8$ & 3 & $<0.001$ & 0.196 \\
\hline & & 4 & $0 \cdot 42$ & 0.58 & 132 & & & & \\
\hline & & (Inoculum & 0.54 & 0.46 & 160) & & & & \\
\hline & & 1 & $0 \cdot 72$ & $0 \cdot 38$ & 25 & & & & \\
\hline 29 & $\mathrm{Xyl}^{+}$ & 2 & $0 \cdot 85$ & $0 \cdot 15$ & 164 & $11 \cdot 4$ & 3 & & 0.104 \\
\hline & & $\mathbf{3}$ & $0 \cdot 87$ & $0 \cdot 13$ & 197 & $11 \cdot 4$ & $\delta$ & $\begin{array}{l}<0.01 \\
>0.001\end{array}$ & 0.104 \\
\hline & & 4 & 0.76 & $0 \cdot 24$ & 222 & & & & \\
\hline & & (Inoculum & 0.45 & 0.55 & 158) & & & & \\
\hline & & 1 & $0 \cdot 78$ & 0.22 & 217 & & & & \\
\hline $\mathbf{3 0}$ & Xyl- & 2 & 0.56 & $0 \cdot 44$ & 94 & & & & \\
\hline & & 3 & $0 \cdot 20$ & $0 \cdot 80$ & 109 & $113 \cdot 4$ & 3 & $<0.001$ & 0.355 \\
\hline & & 4 & $0 \cdot 76$ & $\mathbf{0 \cdot 2 4}$ & 100 & & & & \\
\hline & & (Inoculum & 0.55 & $0 \cdot 45$ & 128) & & & & \\
\hline mocuium & f mixt & 1 & $0 \cdot 58$ & 0.42 & 78 & & & & \\
\hline posed or & and Xyl- & 2 & 0.70 & $0 \cdot 30$ & 66 & $\mathbf{3 5 \cdot 3}$ & 3 & $<0.001$ & 0.208 \\
\hline stock st & trains & 3 & $0 \cdot 49$ & 0.51 & 229 & & & & \\
\hline & & 4 & $0 \cdot 26$ & $0 \cdot 74$ & 101) & & & & \\
\hline
\end{tabular}

The values of $\chi^{2}$ and of $T$ ('Tschuprow's coefficient of variation) are derived from comparisons between mice in each experiment. 
$\chi^{2}$ and $T$ were computed in the same way as those in Table 2.) This heterogeneity would have been remarkable after a dose of $100 \mathrm{LD} 50$ if the mice did not differ in resistance (Fig. 2), but might be expected when the mice did differ as in these experiments. Any mouse of above-average resistance would not have received $100 \mathrm{LD} 50$ in the above control experiment but $<100$ LD 50, and so would be likely to yield a sample differing in composition from that of the challenge dose (see introduction).

Seven abscesses obtained from two surviving mice of the original experiment were examined and all contained a preponderance of the $\mathrm{Xyl}^{+}$variant (Table 6).

Table 6. Mixed-inoculum experiments with Salmonella typhimurium: number of variants found in liver-abscesses of mice surviving inoculation of a mixture of two variants

In the mixed-inoculum experiment shown in Fig. 3 mice surviving 21 days after inoculation were killed, and any liver abscesses seen were dissected out and cultured.

\begin{tabular}{|c|c|c|c|}
\hline \multirow[b]{2}{*}{ Mouse } & \multirow[b]{2}{*}{ Specimen } & \multicolumn{2}{|c|}{ No. of colonies } \\
\hline & & $\mathrm{Xyl}^{+}$ & Xyl \\
\hline a & $\left\{\begin{array}{l}\text { Abscess 1 } \\
\text { Abscess 2 } \\
\text { Abscess 3 }\end{array}\right.$ & $\begin{array}{l}>200 \\
\text { c. } 400 \\
\text { c. } 400\end{array}$ & $\begin{array}{r}2 \\
26 \\
53\end{array}$ \\
\hline b & $\left\{\begin{array}{l}\text { Abscess 1 } \\
\text { Abscess } 2 \\
\text { Abscess } 3 \\
\text { Abscess 4 }\end{array}\right.$ & $\begin{array}{l}\text { c. } 50 \\
\text { c. } 150 \\
\text { c. } 150 \\
\text { c. } 120\end{array}$ & $\begin{array}{l}\mathbf{0} \\
0 \\
0 \\
0\end{array}$ \\
\hline
\end{tabular}

The effect of a terminal breakdown in resistance on the composition of the bacterial population of the heart blood

This experiment was performed to examine the effect of a fatal infection on a concurrent infection by a pathogen of low virulence. Six mice were challenged by intraperitoneal injection with a mixture containing $10^{3}$ of a highly streptomycin-resistant strain of Salmonella paratyphi-B $\left(=10^{-4}\right.$ LD 50 dose) and $10^{3}$ of a virulent streptomycin-sensitive strain of $S$. typhimurium $\left(10^{2}-10^{3}\right.$ LD 50 doses). All the mice died either 3 or 4 days after challenge. Heart blood was removed from each mouse post mortem and plated directly by loop on nutrient agar and on the same medium containing $200 \mu \mathrm{g}$. streptomycin $/ \mathrm{ml}$. In each case, a heavy growth was present on the former plates after $18 \mathrm{hr}$. of incubation at $37^{\circ}$ and between ten and seventy colonies were present on the streptomycin agar. Since heavy inocula of this strain of $S$. typhimurium never produced any colonies on streptomycin agar in control experiments, the colonies appearing on these plates were formed by the streptomycin-resistant strain of $S$. paratyphi-B.

\section{DISCUSSION}

The slopes of the log-dose/probit-mortality curves of the variants of Salmonella paratyphi-B and $S$. typhimurium used in our experiments were 1.81 and $0 \cdot 66$ 
respectively; this observation is therefore compatible with the result predicted by the hypothesis of independent action, namely, that the slope of such curves will never be greater than $2 \cdot 0$. The slopes also showed that the mice differed in their resistance to $S$. typhimurium and possibly to $S$. paratyphi-B. The LD50 doses of the variants of each pathogen did not differ significantly. Each variant was represented with about the same frequency in the heart blood removed post mortem from mice challenged with many LD50 doses of a mixture containing equal parts of all the variants, which showed that there was little difference between their average rates of growth in vivo. They were therefore suitable for use in the experiment with mixed challenge doses.

As predicted by the hypothesis of independent action, the compositions of the bacterial populations of the post-mortem heart blood samples differed more and more from each other and from the composition of the challenge dose as the size of the dose became smaller. However, the predictions of this hypothesis were not completely fulfilled for unexpectedly few heart blood samples from mice dying from 1 or $<1$ LD 50 dose contained only one variant. Many of these samples yielded an excess of one variant with a small proportion (e.g. $\mathbf{0 . 2}$ or less) of the other variant(s). The appearance of the minority was possibly due to a terminal breakdown in resistance caused by the progress of the infection due to the clone descended from only one inoculated bacterium. It is easy to see that such a breakdown might permit the multiplication of other inoculated bacteria, still surviving in the host, to such an extent that they would be present in the heart blood by the time death occurred. This effect was clearly seen when mice were challenged with a lethal dose of Salmonella typhimurium (102-10 $0^{3}$ LD 50 doses) mixed with a non-lethal dose of $S$. paratyphi-B (10-4 LD 50 dose). The dose of the latter was so small that it would not have caused either death or bacteraemia if inoculated by itself. However, these bacteria multiplied and appeared in the heart blood of mice fatally infected by $S$. typhimurium.

We hoped next to have been able to distinguish between the hypotheses of complete independence and of partial synergism but the presence of marked differences in host resistance made this impossible in the Salmonella typhimurium experiments. It is, however, hard to imagine how synergism could occur between the relatively small numbers of bacteria inoculated in those experiments, and we believe that the hypothesis of complete independence, modified by the occurrence of a terminal breakdown in resistance, provides the most satisfactory explanation for our findings. The same considerations apply to the results of challenge by small doses of $S$. paratyphi-B, but there is some evidence that salmonella do not act independently when the dose contains more than $10^{7}$ bacteria. Maaløe (1948) found that the LD 50 dose of an attenuated strain of $S$. typhimurium was reduced when more than $c .10^{7}$ killed organisms of the same species were added to the challenge dose. Under these conditions, the bacteria cannot be acting independently for the presence of one bacterium is clearly influencing the fate of another. For this reason, it is probable that the bacteria only act independently with doses $\leqslant 2$ LD50 of

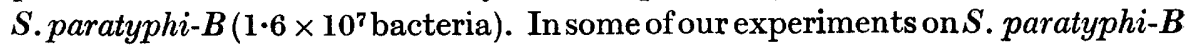


some mice were given as many as $1 \cdot 4 \times 10^{9}$ bacteria intraperitoneally; preliminary experiments showed that the LD50 dose of heat-killed salmonellas given by this route was about $2 \times 10^{10}$ bacteria, so that even with the largest doses given deaths resulted from infection, not from toxicity.

It must be considered whether the hypothesis of maximum synergism could have accounted for the observed results. This predicts that all the inoculated organisms invariably multiply in each fatally infected host. The simplest assumption to make would be that all these organisms multiply at about the same rate so that the blood at the time of death would always contain the variants in about the same proportions as did the challenge dose. Our results clearly exclude this hypothesis, for the observed values of $\chi^{2}$ show that the samples from mice dying from small doses differed in composition far more than could be accounted for purely by chance. It might also be argued that when a considerable number of bacteria multiplied, they might invade the blood stream at different times, so that the host would in fact die from the consequences of multiplication of the one bacterium whose progeny had invaded the blood stream before those of other bacteria. Mice which die from small inocula of salmonellas generally die much later than mice which die from large inocula (e.g. in Expt. 2 of Table 2, all mice given 25 LD 50 doses or more died within $24 \mathrm{hr}$., whereas in mice which died from inocula of 2 LD 50 or less, the median survival time was 6 days). It is possible that the later deaths result from the asynchronous breakdown of localized lesions, each of which may have resulted from the multiplication of only one of the inoculated bacteria; it is to be noted that the abscesses found in survivors appear from their bacterial compositions to have originated in this way. Our data do not exclude this hypothesis but, for reasons given elsewhere, we consider that the hypothesis of independent action is more convincing than its alternatives because it has to be modified by fewer and less restricted assumptions to explain the results of these and of other experiments (see, for example, the discussion of the doseresponse curve given below and experiments by Goldberg, Watkins, Dolmatz \& Schlamm, 1954).

It has been suggested (Peto, 1953) that the hypothesis of independent action applies generally to infective systems in which an all-or-none response is observed. If this were so, then from the argument presented in the introduction, no infective system would yield a log-dose/probit-mortality curve with slope significantly greater than 2. A search of the literature has shown that this prediction is generally fulfilled since only two curves have been traced with slopes significantly greater than 2 (Parker, Bronson \& Green, 1941; Luria \& Dulbecco, 1949). In contrast to these results with infective systems, many curves with slopes significantly greater than 2 are reported in the pharmacological literature (Gaddum, 1933; Bliss \& Cattell, 1943), showing that synergism occurs between drug molecules.

If the hypothesis of independent action is valid, what type of event would enable one organism to be lethal out of a large number administered? One possibility, that the unique bacterium is a mutant of greater virulence or one with a more rapid rate of growth in vivo is excluded in our experiments by 
the control tests in which strains recovered from 'one-variant' infections were combined with the original strains of the other variants. It is theoretically possible, but very implausible, that the unique bacterium differs phenotypically from the majority of the bacteria in such a way that it is certain to multiply and cause a fatal infection, while the rest are of such a kind that they will certainly not so multiply. It seems more probable that the inoculated bacteria are more or less the same in both phenotype and genotype and that the outcome of challenge is determined by chance events occurring in vivo. The injected bacteria can be considered as being distributed amongst host organs and cells of differing resistance. Each bacterium would have a small independent chance of entering an environment that would permit multiplication and the production of a localized lesion. If each lesion had an independent chance of initiating a fatal bacteraemia, then the observed results would be in accord with the predictions of the hypothesis of independent action.

The experiment using mixtures of variants also tests the validity of the terminal dilution method for the isolation of pure clones of viruses. In this method, hosts are challenged with a virus suspension of such a concentration that $\mathbf{P}$ is small. It is assumed that the hosts do not differ in resistance and that the proportion of hosts which responds owing to the growth of one virus particle can be predicted from the Poisson series (Fig. 2). This method will certainly yield pure clones when $p=1$, that is, when the inoculation of one virus particle will invariably produce a response; but when $p<1$, the validity of the method depends on the applicability of the hypothesis of independent action and on the assumption that a terminal decrease in resistance does not occur.

We wish to thank Dr P. Armitage for his help at every stage of this work.

\section{REFERENCES}

Buiss, C. I. \& Cattell, McK. (1943). Biological assay. Ann. Rev. Physiol. 5, 479. Crargie, J. (1931). Studies on the serological reactions of the flagella of B. typhosus. J. Immunol. 21, 417.

Druett, H. A. (1952). Bacterial invasion. Nature, Lond. 170, 288.

Finney, D. J. (1952). Probit Analysis, 2nd ed. Cambridge University Press.

Fismer, R. A. \& Yates, F. (1953). Statistical Tables for Biological, Agricultural and Medical Research, 4th ed. Edinburgh: Oliver and Boyd.

GADDUM, J. H. (1933). Reports on biological standards. III. Methods of biological assay depending on a quantal response. Spec. Rep. Ser. med. Res. Coun., Lond. no. 183. London: H.M. Stationery Office.

Goldberg, L. J., Watkins, H. M. S., Dolmatz, M. S. \& Schramm, N. A. (1954). Studies on the experimental epidemiology of respiratory infections. VI. The relationship between dose of microorganisms and subsequent infection or death of a host. J. infect. Dis. 94, 9.

von HAEbler, T. \& Miles, A. A. (1938). The action of sodium polyanethol sulphonate ('Liquoid') on blood cultures. J. Path. Bact. 46, 245.

Halvorson, H. O. (1935). The effect of chance on the mortality of experimentally infected animals. J. Bact. 30, 330.

Kendall, M. G. (1943). The Advanced Theory of Statistics; Vol. 1, 3rd ed. London: Griffin. 
Kunkel, L. O. (1934). Tobacco and aucuba mosaic infections by single units of virus. Phytopathology, 24, 13.

Lauffer, M. A. \& Price, W. C. (1945). Infection by viruses. Arch. Biochem. 8, 449.

LiU, O. C. \& Henle, W. (1953). Studies on host-virus interactions in the chick embryo-influenza virus system. VII. Data concerning the significance of infectivity titration end-points and the separation of clones at limiting dilutions. J. exp. Med. 97, 889.

Luria, S. E. \& Dulbecco, R. (1949). Genetic recombinations leading to production of active bacteriophage from ultraviolet inactivated bacteriophage particles. Genetics, 34, 93.

MaAløe, O. (1948). I. Pathogenic-apathogenic transformation of Salmonella typhimurium. Acta path. microbiol. scand. 25, 414.

Parker, R. F., Bronson, L. H. \& Green, R. H. (1941). Further studies of the infectious unit of vaccinia. J. exp. Med. 74, 263.

Peto, S. (1953). A dose-response equation for the invasion of micro-organisms. Biometrics, 9, 320.

Sherman, J. M. \& Naylor, H. B. (1942). Ageing without reproduction and the viability of young bacterial cells at low temperatures. J. Bact. 43, 749 .

Stocker, B. A. D., Zinder, N. D. \& Lederberg, J. (1953). Transduction of flagellar characters in Salmonella. J. gen. Microbiol. 9, 410.

Zelle, M. R., Lincoln, R. E. \& Young, G. A. (1946). Respiratory pathogenicity of Bacillus anthracis spores. II. Genetic variation in respiratory pathogenicity and invasiveness of colonial variants of $B$. anthracis. J. infect. Dis. 79, 247.

Zinder, N. D. \& Lederberg, J. (1952). Genetic exchange in Salmonella. J. Bact. 64,679 . 